\title{
Chapter 23 \\ Charcoal Making in the Brazilian Amazon: Economic Aspects of Production and Carbon Conversion Efficiencies of Kilns
}

\author{
SN Swami, C Steiner, WG Teixeira, and J Lehmann
}

\subsection{Introduction}

Charcoal production worldwide is increasing for energy use in households and industry, but it is often regarded as an unsustainable practice and is linked to agricultural frontiers (Prado 2000). The production (Coomes and Burt 1999) and use of charcoal in agriculture is common in Brazil and widespread in Asia (Steiner et al. 2004).

The efficiency of biomass conversion into charcoal becomes important in conjunction with a newly proposed opportunity to use charcoal as a soil conditioner that improves soil quality on very acid and highly weathered soils (Lehmann et al. 2002; Steiner et al. 2004). This can be realized either by charring the entire aboveground woody biomass in a shifting cultivation system as an alternative to slashand-burn (coined recently as slash-and-char by (Glaser et al. 2002; Lehmann et al. 2002) or by utilizing crop residues in permanent cropping systems. Charcoal formation during biomass burning is considered one of the few ways that $\mathrm{C}$ is transferred to refractory long-term pools (Glaser et al. 2001a; Kuhlbusch and Crutzen 1995; Skjemstad 2001). Producing charcoal for soil amelioration instead of burning biomass would result in increased refractory soil organic matter, greater soil fertility and a sink of $\mathrm{CO}_{2}$ if re-growing vegetation (secondary forest) is used. A farmer practicing slash and char could profit from soil fertility improvement and $\mathrm{C}$ credits (if provided by a $\mathrm{C}$ trade mechanism to mitigate climate change), providing a strong incentive to avoid deforestation of remaining primary tropical forests.

Carbonised materials are formally authorized for use as soil amendment material in Japan, which is using $27 \%$ of its national charcoal production $(50,835 \mathrm{t}$ ) for purposes other than fuel, more than $30.6 \%$ of which is used in agriculture (Okimori et al. 2003). In the past Japanese farmers prepared a fertilizer called "haigoe" which consisted of human waste and charcoal powder (Ogawa 1994). Charcoal is proposed to be an important component of the man-made and exceptionally fertile terra preta soils in the Amazon (Glaser et al. 2001b).

This study examines the labour requirements, costs, income, production process and efficiency of making charcoal in rural communities in the Amazon near Manaus, Brazil. The charcoal making process, biomass conversion efficiency, the 
Fig. 23.1 Charcoal is soled together with Terra Preta along roads in the vicinity of Manaus, Brazil (Photo, C. Steiner)

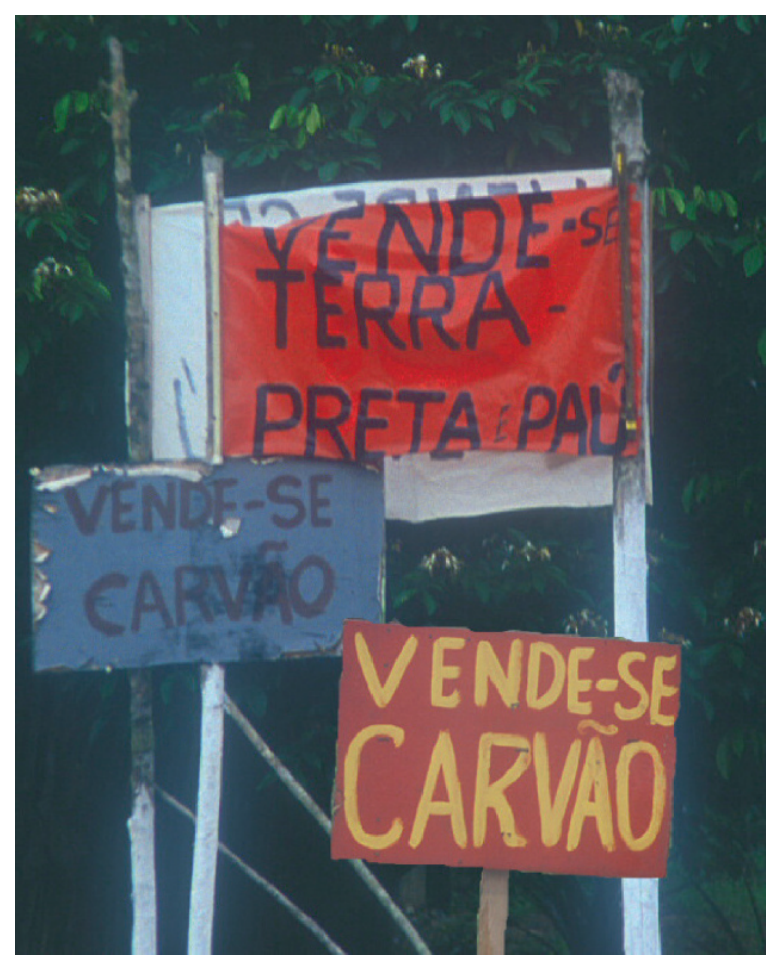

proportion of charcoal waste accumulation and relation to agricultural activities under local small-holder conditions remains largely unknown. Therefore, we addressed the following questions: (1) How much does charcoal making contribute to the household income? (2) How efficient is the charcoal production under local conditions using brick kilns? and, (3) What are the opportunities for using charcoal waste for agriculture? We hypothesized that: (1) Charcoal making is an activity for the poorest households; (2) Access to markets is the largest constraint for small scale charcoal producers; (3) The conversion efficiency of wood to charcoal is low; and, (4) Significant amounts of charcoal waste is produced by charcoal making using brick kilns and can be used for agriculture (Fig. 23.1).

\subsection{Materials and Methods}

\subsubsection{Study Site}

Primary research was carried out in the Tarumã Mirim settlement situated at $21 \mathrm{~km}$ on the BR 174 highway that links Manaus, Amazonas to Boa Vista, Roraima. It was created in 1992 as an agricultural settlement by INCRA (Instituto de Nacionalização 
Colonização e Reforma Agrária or the National Institute for Colonization and Agricultural Reform) and is situated between the streams of Tarumã Açu and Tarumã Mirim. The total area of the settlement is 4,291,076 ha, consisting of 1,042 lots of an average of 25 ha each, of which 944 lots were occupied as of July 2003. The location was chosen because local key informants, as well as secondary sources such as institutional and governmental reports, surmised that a large number of inhabitants make charcoal for sale. The settlement was originally created to promote the adequate occupation of the area through the absorption of potential farmers without land who live in marginalized conditions in Manaus. Around $75 \%$ of residents have been living there for 2-5 years, and approximately $70 \%$ of residents are from Amazonas State. There are many internal side roads, totalling $74 \mathrm{~km}$, and all roads in the settlement are unpaved. Other areas in the region were also explored on an informal basis as a source of information on charcoal making activities near Manaus, including the banks of the BR-174 highway and the settlement Canoas/Rio-Pardo. The latter was created by INCRA for the same purposes as Tarumã Mirim.

\subsubsection{Surveys}

The households in the chosen settlement of Taruma Mirim were selected by driving along the main road and stopping at every three houses to solicit information on households that make charcoal within the nearest four or five houses. There is no census or other database of charcoal producers in settlements.

Interviews were conducted with the charcoal makers who were present at the time of the field visits. A total of 18 households who make charcoal were interviewed. First, a questionnaire was tested over the space of 1 month, and then revised in order to obtain more accurate information. The interviews solicited both quantitative and qualitative socio-economic information and were semi-structured in format and in-depth in nature. The qualitative information was verified by triangulation to the extent possible, including information from key informants, from public and government institutions, interviews with charcoal retailers in the city and written documents from various governmental and educational institutions. Economic returns, as well as more general information about production techniques, risks, labour requirements and the use of charcoal waste (powder, broken and unmarketable pieces) in agriculture were examined.

\subsubsection{Biomass Conversion Efficiency}

In order to assess the charcoal production progress and biomass conversion efficiency, four of the land owners interviewed were randomly selected and invited to assist measuring the weight of wood trunks, charcoal yield, remaining unburnt 
wood and charcoal waste (unmarketable broken pieces and powder). A balance with a capacity of $150 \mathrm{~kg}$ was used to weigh each bag individually. The $\mathrm{C}$ balance was examined by sampling disk shaped cross sections of wood trunks for each tree species that were loaded into each of the four kilns (hereon referred to as kilns A, B, C and D). A quarter of each of the cross sections was cut, dried, weighed and ground into a fine powder. Three composite samples from this fine powder were prepared for each species used in each one of the four kilns. The composite samples were analyzed for $\mathrm{C}$ content by dry combustion with an automatic $\mathrm{C} / \mathrm{N}$ - analyzer (Elementar, Hanau, Germany) to determine the quantity of $\mathrm{C}$ entering each kiln in the form of wood. Randomly chosen charcoal samples were analyzed for their $\mathrm{C}$ content using the same analyzer.

The maximum temperature inside a kiln was measured using a brick marked with heat crayons and wrapped in aluminium foil. The bricks were placed inside the four kilns and remained there during the entire carbonization process. Ten crayon marks, each of a different colour, were made on each brick. Each crayon is manufactured to change colour at calibrated melting points in the range of $120^{\circ} \mathrm{C}$ to $600^{\circ} \mathrm{C}$. At the end of the process, when the kiln was opened, the tile was retrieved to assess the changed colour according to the maximum temperature reached inside the kiln.

\subsubsection{Statistical Analyzes}

An ordinary least squares (OLS) linear regression was done to obtain an idea on what factors influence a household's charcoal productivity. A forward stepwise linear regression of the productivity (number of charcoal sacks produced) of a household was done.

\subsection{Results and Discussion}

\subsubsection{Production Process}

Charcoal is made in brick and earth kilns. Most kilns are located on the forest edge, thus facilitating easy access to the kiln feedstock. Although most charcoal producers have some knowledge of which tree species become good charcoal, they simply cut as much wood as needed to fill the kilns without any selection of tree species. However, some indicated a preference for wood from trees that had undergone considerable drying, as this wood tended to give more intact charcoal pieces. In a conventional kiln the water content strongly affects the reaction time and charcoal yield negatively, if not pressurized (Antal and Grønli 2003). The mean moisture content of the feed stock was $17 \%$. Freshly cut wood from standing trees renders 
charcoal that tended to break and increase the formation of unmarketable charcoal powder. Thin branches and twigs are not used in this process since they are apt to burn and produce flames; hence, tree trunks and large, thick branches are preferred. After the kiln is filled a small fire is ignited at the kiln entrance. Later, the door is sealed with clay and the wood is left to undergo incomplete combustion (forming charcoal). The temperature inside the brick kiln was found to be between $470^{\circ} \mathrm{C}$ and $600^{\circ} \mathrm{C}$. The combustion process can be regulated by sealing and opening vents with clay. Finally, the kiln and all the vents are sealed and coated in order stop the combustion process. Once the kiln has cooled sufficiently, it is opened and the charcoal placed in bags to sell.

\subsubsection{Labour and Household Productivity}

Those households making charcoal $(n=18)$ have been doing so for 3.4 years on average $( \pm 1.7)$ and $50 \%$ own one kiln, $33 \%$ own two kilns and $17 \%$ own three or more kilns. For the majority $(56 \%)$ charcoal production is the only source of income. A kiln with a capacity to produce 100 sacks of charcoal costs between 45 and 67 USD (100-150 BRL) to build, including the costs of bricks and other tools; but the costs can be considerably higher if the charcoal producer hires labour for construction help. The model shows that household charcoal productivity increases significantly with the number of people working, the man-days of labour and the number of household income sources. A forward stepwise linear regression of the productivity (number of sacks of charcoal produced) of a household gives:

$$
Y=-204.3+190.4 a+13.71 b+90.1 c-115.3 d
$$

$Y=$ Monthly charcoal sacks produced per household

$a=$ Number of people who are hired $\left(\mathrm{R}^{2}=0.839, P<0.05\right)$

$b=$ Man-days of labour $\left(\mathrm{R}^{2}=0.839, P<0.05\right)$

$c=$ Number of sources of income $\left(\mathrm{R}^{2}=0.839, P<0.05\right)$

$d$ = categorical variable that indicates whether the charcoal is sold in Manaus (1) or not (0)

Charcoal making is a highly labour intensive activity that provides small returns (Table 23.1). The cost of raw materials for producing 100 sacks of charcoal is $\mathrm{R} \$$ 85 (38 USD). A charcoal producer takes, on average, nine man-days to make 100 bags of charcoal (1 day to cut wood, 1 day to fill and set fire, 3-4 days for pyrolysis supervision, 2-3 days to cool the kiln and 1 day to extract and bag the charcoal). Depending on whether he sells charcoal in the settlement or in the city, he earns either R \$ 2.50 (1.1 USD) or R \$ 6.50 (3.0 USD), respectively, for each bag of charcoal measuring the equivalent of four $20 \mathrm{~L}$ cans. Dividing the charcoal produced by the number of filled sacks at the producer gave a mean sack weight of $23.5 \mathrm{~kg}$ (Steiner et al. 2004) measured a mean sack weight of $15 \mathrm{~kg}$ at a roadside market. 
Table 23.1 Economic returns and differences between solely charcoal makers (SC) and additional charcoal makers (AC)

\begin{tabular}{lll}
\hline & $\mathrm{SC}(n=14)$ & $\mathrm{AC}(n=4)$ \\
\hline Average production costs per 100 $\mathrm{sacks}^{\mathrm{b}}\left(\mathrm{USD}^{\mathrm{a}}\right)$ & 38.4 & 38.4 \\
Man-days required to produce $100 \mathrm{sacks}^{\mathrm{b}}$ & 9 & 9 \\
Average selling price per sack/ton $\left(\mathrm{USD}^{\mathrm{a}}\right)$ & $1.13 / 47.5$ & $2.93 / 123.1$ \\
No. sacks/Mg produced per month & $230( \pm 165) / 5.5$ & $643( \pm 200) / 15.3$ \\
Net income per month from charcoal sales $\left(\mathrm{USD}^{\mathrm{a}}\right)$ & $172( \pm 150)$ & $>1,200( \pm 90)$ \\
No. sources of income & 1 & $>1$ \\
Charcoal production every month & Yes & No \\
Access to private transportation & No & Yes \\
Directly involved in production & Yes & No \\
Charcoal soled in Manaus? & No & Yes \\
\hline
\end{tabular}

${ }^{\mathrm{a}} 1 \mathrm{USD}=2.22$ BRL (November 28 2005).

${ }^{\mathrm{b}}$ Average sack weight at the producer is $23.8 \mathrm{~kg}$.

All of the assessed charcoal making in the Tarumã Mirim settlement took place on the producer's own land. Two groups of charcoal producers could be distinguished (Table 23.1). The first group (solely charcoal makers, SC) is heavily dependent on charcoal as the principal source of income throughout the year. They make charcoal because their agricultural activities failed to provide them with an adequate income; hence, taking advantage of the natural vegetation (evergreen tropical rainforest). Their monthly income is highly variable; being influenced by their financial ability to hire labour, to pay for motor saw fuel, sacks to bag the charcoal and transportation. It was common to see settlers unable to meet many of the above conditions. All SC sell charcoal to middlemen since they have no access to transportation.

The second group (additional charcoal makers, AC) consists of those who are not dependent on charcoal as their principal source of income. Charcoal producers in this group have usually employment in the city. They produce charcoal as a supplement to their income and also to take advantage of deforestation by planting crops. All have access to private transportation that enables them to transport and sell charcoal in the city at higher prices and their income and productivity is not as variable as that of SC.

On the BR-174 highway (on which both settlements are located), considerable charcoal production is on lands belonging to large ranchers. The owners do not directly provide any income, instead letting charcoal producers utilize the wood in return for labour that clears his land. Once the land has been sufficiently cleared for agricultural production, the charcoal producer moves on to the next site where such an exchange can take place.

SC producers especially emphasized troubles to produce and market agricultural goods and all the producers in this group had trouble growing enough even at a subsistence level. The earnings from selling charcoal contributed much to purchase food from the city for such households. Neither group had a stable source of market based agricultural activities, although this settlement, like most others, was originally formed with the intention to provide land for agriculture to potential farmers. 


\subsubsection{Charcoal Market and Waste}

In informal interviews at the charcoal market, charcoal sellers stated that for each of seven sales-posts, between 1,000 and 2,000 large sacks, and between 600 to 1,000 small sacks $(\sim 2 \mathrm{~kg})$ of charcoal were sold every week. The charcoal sellers also stated that since they break down the charcoal into smaller pieces for selling, there is considerable powder left over. The powder is usually purchased by farmers of Japanese descent. Sacks of charcoal powder are sold for R $\$ 0.50$ (0.23 USD) each. The selling can be considered as a way to get rid of the wastes, because only the price of the sack is gained. The charcoal sellers stated that typically all the powder is sold out.

\subsubsection{Conversion Efficiency, Carbon Balance and Agricultural Use}

The mean charcoal recovery by weight of wood biomass was $25.3 \%(n=3)$ and the charcoal had a C content of 76.6\%. Kiln B was an earthen kiln and had very little wood feedstock, which might explain the low conversion efficiency. The successful carbonization of the wood mainly depends on the condition of the kiln. Traditional kilns in Madagascar and Rwanda realize efficiencies of only 8-9\%, while elsewhere efficiencies are in the range of 8-36\% (reviewed by Antal and Grønli (2003). The mean $\mathrm{C}$ yield (C wood*100/C charcoal) was $41.6 \%(n=3)$ and ranged from $31 \%$ to $56 \%$. The mean proportion of charcoal waste was $12.3 \%$ of the charcoal produced at the production site and the $\mathrm{C}$ in the waste made up $3.7 \%$ of the wood $\mathrm{C}$ content (Table 23.2). Lehmann et al. (2002) calculated the average recovery of charcoal and $C$ from woody biomass. They found that the average recovery of charcoal mass from woody biomass is $31 \%$, the $\mathrm{C}$ recovery is $54 \%$ and the mean $\mathrm{C}$ content of charcoal is $76 \%$.

Table 23.2 Biomass conversion into charcoal

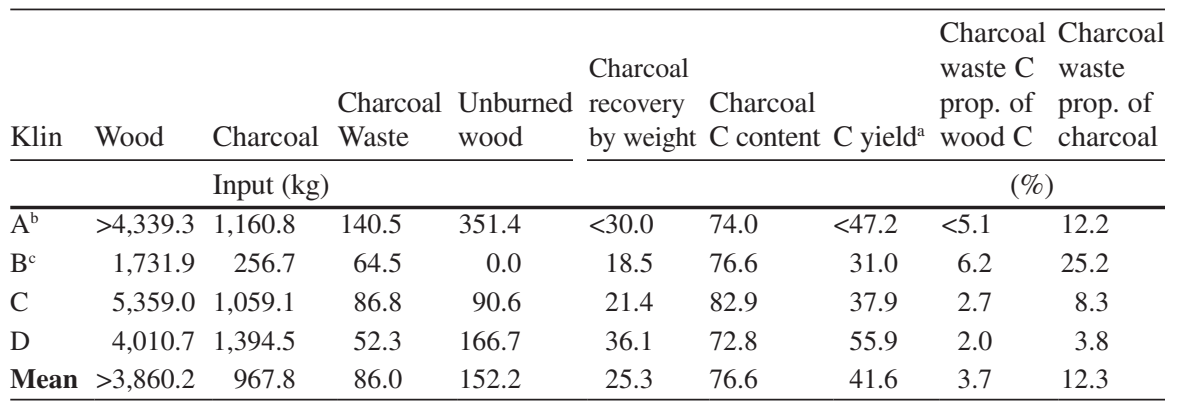

aPercentage of charcoal carbon from the carbon in wood. average c in biomass was $47 \%$.

${ }^{\mathrm{b}}$ Biomass input was not entirely assessed.

'Earth kiln. 
Around Cali, Colombia, charcoal waste from local production was determined to be $30 \%$ to $40 \%$ of the total production (Lehmann et al. 2006). We determined a mean waste generation of only $12.3 \%$ at the producer. Given the considerable waste accumulation at the charcoal market in Manaus we assume that the percentage is much higher after transport, breaking of big logs and re-bagging.

None of the charcoal makers interviewed used charcoal powder as a soil conditioner in a systematic way. Also, it appears that many charcoal producers are not aware that charcoal powder is a commodity in the markets of Manaus, where it is bought by other farmers who have a cultural history of using it for instance to mix it with poultry feed (Steiner et al. 2004). Charcoal use might strongly depend on the ability to produce agricultural goods and, thus, depending on the ability of farmers to buy fertilizer and use fertilizer in a proper way. Most SC producers have not enough income to invest in their lands and an additional nutrient source is necessary to benefit from charcoal applications (Lehmann et al. 2003; Steiner et al. 2004). There are important differences between charcoal producers that influence whether charcoal wastes can be used in agriculture successfully from an economic point of view. SC producers may not find the use of charcoal for soil amelioration purposes to have much incremental benefits for them since they rely on charcoal sales for survival, are limited by labour and are lacking in capital assets that would enable them to reach the market and sell their goods (including crops) at higher prices. AC producers, however, have better economic means that may enable them to use charcoal and invest in long term soil fertility improvement. The charcoal waste or, indeed, some of the charcoal itself in powdered form could be used in agriculture without adversely affecting the household's well-being.

At a burn of forest being converted to cattle pasture only $2.7 \%$ of above-ground C being converted to charcoal (Fearnside et al. 2001). Seiler and Crutzen (1980) were the first to point out the potential importance of charcoal formation to the global C cycle. Fearnside et al. (2001) found that the average $\mathrm{C}$ content for charcoal formed by slash-and-burn was $73 \%$, which is close to the $\mathrm{C}$ content of charcoal formed in the studied kilns. From the results of this study, forming charcoal in earthen kilns or brick kilns converts $31 \%$ to $56 \%$ of feedstock C into charcoal C. Hence, making charcoal with the specific purpose of using it or the waste as a soil conditioner could be one way to increase the amount of $\mathrm{C}$ in the soil; benefiting the farmer by providing him with a land clearing method that increases SOM in the form of recalcitrant black $\mathrm{C}$ and reducing the smoke emissions by controlled perennial (charcoal making is not restricted to the dry season) conversion. As charcoal waste is making up $2.0 \%$ to $6.2 \%$ of original $\mathrm{C}$ in the biomass (not including further waste creation during charcoal breaking, marketing and bagging) more $\mathrm{C}$ remains as refractory SOM in the soil as considering the slash-and-burn scenario even if just the waste were used for soil amelioration and the marketable pieces are sold. Charcoal waste accumulation in Colombia was determined to be $30 \%$ to $40 \%$ of the charcoal produced (Lehmann et al. 2006). Other sources report that $20 \%$ remains as charcoal powder and pieces (FAO 1991). AS producers seem likelier to have enough resources to establish a slash and char system. However, financial benefits provided by an international $\mathrm{C}$ trade mechanism would particularly enable and 
motivate SC producers to invest in soil fertility and, thus, in their own and the settlement's future.

Currently (November 28, 2005), 1 t of $\mathrm{CO}_{2}$ is traded for 24 USD in Europe. One ton of charcoal produced in Amazonian kilns is the equivalent of $2.81 \mathrm{Mg}$ of $\mathrm{CO}_{2}$ $\left(\mathrm{C}\right.$ content of charcoal $(0.766) \times(3.66) \mathrm{CO}_{2} / \mathrm{C}$ weight balance). Providing a SC producer access to the $\mathrm{C}$ trade market would raise the value of his charcoal from 48 USD per ton to 67 USD per ton. In this case it is more likely that SC producers implement a slash and char system than AC producers because the later are able to sell their charcoal for 123 USD per ton. According to Steiner et al. (2004) charcoal is sold by a producer with access to a road side market for 90 USD per ton. In reality, a bargaining process will determine how much $\mathrm{C}$ is used for soil amelioration (sequestration) or for energy use (fossil fuel substitution). Both cases reduce the amount of greenhouse gas in the atmosphere; the first by sequestering $\mathrm{CO}_{2}$ and the second by avoiding emissions as long as the use of re-growing biomass is insured. According to Coomes and Burt (1999) fallows of between 8 and 12 years are sufficiently long for both charcoal production and agricultural cultivation and the regeneration of forest with primary forest species is much greater in areas that were not burned after felling and, instead, one used for charcoal production (Prance 1975). An access to the $C$ trade market holds out the prospect to reduce or eliminate the deforestation of primary forest, because using intact primary forest would reduce the farmer's C credits. Fearnside (1997) estimated the above-ground biomass of unlogged forests to be $434 \mathrm{Mg} \mathrm{ha}^{-1}$, about half of which is $\mathrm{C}$. This $\mathrm{C}$ is lost if burned in a slash-and-burn scenario and lost to a high percentage if used for charcoal production. The $\mathrm{C}$ trade could provide an incentive to cease further deforestation; instead reforestation and recuperation of degraded land for fuel and food crops would gain magnitude. As tropical forests account for between $20 \%$ and $25 \%$ of the world terrestrial C reservoir (Bernoux et al. 2001), this consequently reduces emissions from tropical forest conversion which is estimated to contribute globally as much as $25 \%$ of the net $\mathrm{CO}_{2}$ emissions and up to $10 \%$ of the $\mathrm{N}_{2} \mathrm{O}$ emissions to the atmosphere (Palm et al. 2004). According to Lehmann et al. (2006) slash and char as alternative to slash-and-burn could off-set $12 \%$ of the annual anthropogenic $\mathrm{C}$ emissions caused by land use change. From our calculations a farmer is capable of increasing the soil $\mathrm{C}$ content on 1 ha in the top $0.1 \mathrm{~m}$ soil depth from $0.9 \%$ to $20 \%$ annually if just the waste were used in SC production system or all charcoal is used in an AC production system, respectively (Table 23.3). Already the low charcoal additions of $13.3 \mathrm{Mg} \mathrm{Cha}^{-1}$ improved tree height and stem diameter of Inga edulis significantly and was equivalent to fertilizer applications (Lehmann et al. 2002). Only $11 \mathrm{Mg} \mathrm{ha}^{-1}$ charcoal application could almost double the overall yield (four cropping cycles) from mineral fertilized plots in comparison from that achieved on mineral fertilized plots alone (Steiner et al. 2007).

The process of producing charcoal in kilns is also very hazardous to the health (Tzanakis et al. 2001), since the charcoal producer is exposed to heat and large amounts of charcoal powder and dust. Thus, any conscientious attempt to involve and encourage farmers to produce charcoal should investigate alternative production methods that are much less damaging to health and offer the advantage of 
Table 23.3 Potential soil C increase and carbon sequestration value under different scenarios

\begin{tabular}{lccc}
\hline $\begin{array}{l}\text { Scenario } \% \text { of } \\
\text { charcoal for } \\
\text { agricultural use }\end{array}$ & $\begin{array}{l}\text { Annual amount } \\
\text { of charcoal for } \\
\text { soil }(\mathrm{Mg})\end{array}$ & $\begin{array}{l}\text { Soil C increase } \\
1 \text { ha in top } 0.1 \mathrm{~m} \\
\text { soil depths }(\%)\end{array}$ & $\begin{array}{l}\text { Potential carbon } \\
\text { sequestration value (USD) }\end{array}$ \\
\hline SC waste $12.3^{\mathrm{a}}$ & 8.1 & 0.88 & 546 \\
SC waste $35^{\mathrm{b}}$ & 23.1 & 2.51 & 1,557 \\
AC waste $12.3^{\text {a }}$ & 22.6 & 2.45 & 1,523 \\
AC waste $35^{\text {b }}$ & 64.3 & 6.98 & 4,334 \\
SC 100 & 66.0 & 7.17 & 4,449 \\
AC 100 & 183.6 & 20.0 & 12,376 \\
\hline
\end{tabular}

${ }^{\mathrm{a}} 12.3 \%$ of charcoal waste accumulation at the producer.

${ }^{\mathrm{b}}$ Charcoal waste generation estimated by Lehmann et al. (2005).

utilizing by-products like energy and liquid fuels. The distillation of the pyroligneous acid fraction from the smoke is often part of the charcoal manufacturing processes in southern parts of Brazil (Glass 2001). Another system in development converts biomass into a hydrogen-rich gas producing charcoal as a by-product (Day et al. 2005). Such an integrated approach facilitates the utilization of any kind of wet biomass (crop residues, small branches and twigs) for energy and agricultural char production. Using other biomass sources for agricultural char production would not hamper the production of barbecue charcoal (from bigger logs for fossil fuel substitution).

\subsection{Conclusion}

There are important social and economic distinctions within charcoal producers at the household level. Charcoal making in most cases appears to be a "last resort" activity, especially among small farmers with few monetary resources. Most of these farmers would only consider charcoal making when under monetary pressure due to a failure of agricultural activities. For those who find themselves in such a situation, making charcoal from wood is a way to take advantage of the resources at their disposal in order to substitute for the income making capacity of agriculture. Yet others make charcoal to supplement other primary sources of income and are not reliant on charcoal for survival needs. This group has the financial strength for selling charcoal with high economic returns, as well as for agricultural production depending on fertilizer input.

Production of charcoal shows promise as an agent for $\mathrm{C}$ sequestration, especially given the quite efficient $\mathrm{C}$ conversion in brick kilns. Charcoal waste is a significant proportion of the total charcoal yield and can be used as soil conditioner to increase soil fertility and crop productivity in acid and highly weathered soils by transferring labile $\mathrm{C}$ into a refractory soil $\mathrm{C}$ pool. Even if the sold and burned charcoal does not sequester $\mathrm{C}$ it is still substituting fossil energy and, thus, reducing greenhouse gas emissions if a re-growing biomass source (secondary forest) is used instead of in-field 
burning. Amounts of charcoal waste produced at the production site are higher than charcoal produced by slash-and-burn events. A further large proportion of waste is generated during marketing and bagging of charcoal which is usually collected for agricultural purposes at the city market. More information is needed on the agronomic facilities, the potential to use alternative biomass sources and production of by-products to evaluate the opportunities for adopting a slash and char system. The access to a global $\mathrm{C}$ trade mechanism would facilitate charcoal use for soil amelioration and, thus, reducing climate change and further deforestation.

Acknowledgments The authors would like to thank Cornell University for funding, and EMBRAPA Amazonia Ocidental and INPA (Instituto Nacional de Pesquisas da Amazonia) for valuable assistance throughout all stages of the study. A financial contribution was given by the doctoral scholarship programme of the Austrian Academy of Sciences.

\section{References}

Antal MJ and Grønli M (2003) The art, science, and technology of charcoal production. Industrial \& Engineering Chemistry Research 42: 1619-1640

Bernoux M, Graça PMA, Cerri CC, Fearnside PM, Feigl BJ and Piccolo MC (2001) Carbon storage in biomass and soils. In: McClain ME, Victoria RL and Richey JE (eds) The Biogeochemistry of the Amazon Basin. Oxford University Press, New York, pp. 165-184

Coomes OT and Burt GJ (1999) Peasant charcoal production in the Peruvian Amazon: Rainforest use and economic reliance. Forest Ecology and Management 140: 39-50

Day D, Evans RJ, Lee JW and Reicosky D (2005) Economical $\mathrm{CO}_{2}, \mathrm{SO}_{\mathrm{x}}$ and $\mathrm{NO}_{\mathrm{x}}$ capture from fossil-fuel utilization with combined renewable hydrogen production and large-scale carbon sequestration. Energy 30: 2558-2579

FAO (1991) Charcoal Production and Pyrolysis Technologies. Food and Agricultural Organization of the United Nations, Rome, Italy

Fearnside PM (1997) Greenhouse gases from deforestation in Brazilian Amazonia: Net committed emissions. Climatic Change 35: 321-360

Fearnside PM, Lima PM, Graça A and Rodrigues FJA (2001) Burning of Amazonian rainforest: Burning efficiency and charcoal formation in forest cleared for cattle pasture near Manaus, Brazil. Forest Ecology and Management 146: 115-128

Glaser B, Guggenberger G, Haumaier L and Zech W (2001a) Persistence of soil organic matter in archaeological soils (Terra Preta) of the Brazilian Amazon region. In: Rees RM, Ball BC, Campbell CD and Watson CA (eds) Sustainable Management of Soil Organic Matter. CAB International, Wallingford, CT, pp. 190-194

Glaser B, Haumaier L, Guggenberger G and Zech W (2001b) The "terra preta" phenomenon: A model for sustainable agriculture in the humid tropics. Naturwissenschaften 88: 37-41

Glaser B, Lehmann J and Zech W (2002) Ameliorating physical and chemical properties of highly weathered soils in the tropics with charcoal - a review. Biology and Fertility of Soils 35: 219-230

Glass V (2001) Reportagens Tecnologia-Onde há fumaça há lucro. Globo Rural 188

Kuhlbusch TAJ and Crutzen PJ (1995) Toward a global estimate of black carbon in residues of vegetation fires representing a sink of atmospheric $\mathrm{CO}_{2}$ and a source of $\mathrm{O}_{2}$. Global Biogeochemical Cycles 9: 491-501

Lehmann J, da Silva Jr JP, Rondon M, Cravo MdS, Greenwood J, Nehls T, Steiner C and Glaser B (2002) Slash and char - a feasible alternative for soil fertility management in the central Amazon? 17th World Congress of Soil Science, Bangkok, Thailand, pp. 1-12 
Lehmann J, da Silva Jr JP, Steiner C, Nehls T, Zech W and Glaser B (2003) Nutrient availability and leaching in an archaeological Anthrosol and a Ferralsol of the Central Amazon basin: Fertilizer, manure and charcoal amendments. Plant and Soil 249: 343-357

Lehmann J, Gaunt J and Rondon M (2005) Bio-char sequestration in terrestrial ecosystems - a review. Mitigation and Adaptation Strategies for Global Change 11: 403-427

Ogawa M (1994) Symbiosis of people and nature in the tropics. Farming Japan 28(5): 10-30

Okimori Y, Ogawa M and Takahashi F (2003) Potential of $\mathrm{CO}_{2}$ emission reductions by carbonizing biomass waste from industrial tree plantation in south Sumatra, Indonesia. Mitigation and Adaptation Strategies for Global Change 8: 261-280

Palm C, Tomich T, van Noordwijk M, Vosti S, Gockowski J, Alegre J and Verchot L (2004) Mitigating GHG emissions in the humid tropics: Case studies from the alternatives to slashand-burn program (ASB). Environment, Development and Sustainability 6: 145-162

Prado M (2000) The environmental and social impacts of wood charcoal in Brazil. Wild Images, Rio de Janeiro, p. 192

Prance GT (1975) The history of the INPA capoeira based on ecological studies of Lecythidaceae. Acta Amazonica 5: 261-263

Seiler W and Crutzen PJ (1980) Estimates of gross and net fluxes of carbon between the biosphere and the atmosphere from biomass burning. Climatic Change 2: 207-247

Skjemstad J (2001) Charcoal and other resistant materials. In: Net Ecosystem Exchange Workshop Proceedings, Canberra ACT 2601, Australia, pp. 116-119

Steiner C, Teixeira WG and Zech W (2004) Slash and char: An alternative to slash and burn practiced in the Amazon Basin. In: Glaser B and Woods WI (eds) Amazonian Dark Earths: Explorations in Space and Time. Springer, Heidelberg, pp. 183-193

Steiner C, Teixeira WG, Lehmann J, Nehls T, Macêdo JLVd, Blum WEH and Zech W (2007) Long term effects of manure, charcoal and mineral fertilization on crop production and fertility on a highly weathered Central Amazonian upland soil. Plant and Soil 291: 275-290

Tzanakis N, Kallergis K, Bouros DE, Samiou MF and Siafakas NM (2001) Short-term effects of wood smoke exposure on the respiratory system among charcoal production workers. Chest 119: $1260-1265$ 